\title{
Compressibility Behaviour of Peat Reinforced with Single and Multiple Deep Soil Mixing (DSM) Columns
}

\author{
M.S.S. Haakeel, M.Z.M. Ramzi and M.C.M. Nasvi
}

\begin{abstract}
Peat represents an extreme form of soft soil and it poses serious problems in construction due to its long-term consolidation settlement even when subjected to a moderate load. Hence, suitable geotechnical design parameters and construction techniques are needed for this type of ground condition. Deep soil mixing (DSM) method is one of the widely used chemical methods of ground improvement for soft clay. However, DSM technique is quiet new for peat. Hence, aim of this research was to study the compressibility behaviour of peat stabilized with fly ash using DSM technique. A series of Rowe Cell consolidation experiments was conducted on peat and peat stabilized with fly ash. For the stabilization, $50 \%$ of fly ash was added to peat and single and multiple deep mixing columns were formed. Based on the outcome of this research, it was noticed that compressibility parameters such as compression index $\left(\mathrm{C}_{\mathrm{c}}\right)$ and swell index $\left(\mathrm{C}_{\mathrm{s}}\right)$ reduce with the addition of fly ash. Percentage reductions in $\mathrm{C}_{\mathrm{c}}$ by the addition of stabilized single and multiple columns (for column area ratio of $16 \%$ ) were $27.3 \%$ and $39.4 \%$ respectively compared to raw peat, while the reductions in $C_{s}$ were $37.6 \%$ and $62.5 \%$ respectively for single and multiple columns. In addition, it was noticed that shear strength parameters of peat $\left(c^{\prime}\right.$ and $\left.\varphi^{\prime}\right)$ can be significantly improved by stabilizing with fly ash. On the whole, DSM technique is applicable for peat, and for a given area ratio, multiple DSM columns are more effective in reducing the compressibility compared to asingle DSM column.
\end{abstract}

Keywords: Compressibility, Compression index, Deep soil mixing, Fly ash, Peat

\section{Introduction}

Peat is formed from the accumulation of partially decomposed and disintegrated plant in certain type of ecosystem in which water is abundant [9]. It possesses unfavourable characteristics such as low strength, low bearing capacity, medium to low permeability, high compressibility, high water holding capacity and high rate of creep $[9,15]$. Peat covers about $5-8 \%$ of earth's surface and two-thirds of the total world coverage of peat is in South East Asia [9]. Peat covers approximately 2.4 million ha of land area in Malaysia [13] while 25000 ha of land is covered by peat in Sri Lanka [15]. As the coverage of peat is quite extensive and the available land space is limited, peat land should be used for construction to meet the demand for land. Therefore, appropriate ground improvement techniques are needed for this type of ground conditions. There are two methods of ground improvement used for soft soils: (1) Mechanical method and (2) Chemical method. Mechanical method includes displacement and replacement, stage construction and preloading, stone columns, piles, vertical drains and light weight fill $[2,11$, $12,16]$.
In the chemical method, a chemical stabilizer is used to stabilize the soil by chemical reaction between the soil and additives $[1,3,4,6,7]$. Deep soil mixing (DSM) is a method of chemical ground improvement that involves mechanical mixing of in-situ weak soft soil with a cementitious compound [3]. Use of DSM technique is very popular for soft clay but it is yet to be proven for peat [3]. Therefore, this research focuses on the applicability of the DSM technique for Sri Lankan peat soil. There are many studies $[5,6,7,8,14]$ focusing on the stabilization behaviour of peat using chemical admixtures and the following section summarizes the findings of those studies.

\footnotetext{
Mr. M.S.S. Haakeel, B.Sc. Eng. (Hons.) (Peradeniya), Department of Civil Engineering, University of Peradeniya. Email:haakeels@gmail.com

ORCID ID: http://orcid.org/0000-0001-6361-1640

Mr. M.Z.M. Ramzi, B.Sc. Eng. (Hons.) (Peradeniya), Department of Civil Engineering, University of Peradeniya. Email:ramzi.m@eng.pdn.ac.lk

ORCID ID: http://orcid.org/0000-0001-7659-5723

Eng. (Dr.) M.C. M. Nasvi, B.Sc. Eng. (Hons.) (Peradeniya), Ph.D. (Monash), AMIE (Sri Lanka), Senior Lecturer of Civil Engineering, Department of Civil Engineering, University of Peradeniya.

Email:nasvimom@eng.pdn.ac.lk

ORCID ID: http://orcid.org/0000-0002-4936-9963
} 
Huat et al. [6] carried out a detailed study to investigate the compressibility behaviour of peatsoil stabilized with Ordinary Portland Cement (OPC) using deep mixing method (DMM).

The DMM columns had been formed by mixing cement with peat in different proportions (cement: peat ratios of 50:50, 70:30, 80:20 and 90:10). For 28 day-cured samples, Rowe cell tests had been performed to evaluate the compressibility characteristics. The results showed that the compressibility parameters such as compression index $\left(\mathrm{C}_{\mathrm{c}}\right)$ and secondary compression index $\left(C_{a}\right)$ of peat can be improved significantly by the installation of cement stabilized columns. The amount of cement used to form a column and its diameter had been observed to influence the compressibility behaviour of peat.

Sing et al. [14] investigated early age strength gain characteristics of stabilized peat to formulate a suitable and economical mix design that could be effectively used for the soil stabilization. To achieve the objective, the study examined the effect of binder, sodium chloride as cement accelerator and siliceous sand as filler on the unconfined compressive strength (UCS) of stabilized peat soils after 7 days of curing. Binders used to stabilize the peat had been OPC, ground granulated blast furnace slag (GGBS), sodium bentonite (SB), kaolinite, lime and bentonite. The test results revealed that the stabilized peat specimen (80\% OPC: $10 \%$ GGBS: $10 \%$ SB) with addition of $4 \%$ sodium chloride by weight of binder and 50\% well graded siliceous sand by volume of wet peat at $300 \mathrm{~kg} / \mathrm{m}^{3}$ binder dosage had yielded the highest UCS value of 196 $\mathrm{kPa}$. The findings implied that, the higher the dosage of siliceous sand in stabilized peat, the more solid particles had been available for the binder to unite and form a load sustainable stabilized peat.

Duraisamy et al. [3] investigated the effects of cylindrical column diameter on the compressibility of fibrous peat reinforced with cement. Specimens with $45 \mathrm{~mm}$ in diameter (area ratio $=0.09$ ) and $60 \mathrm{~mm}$ in diameter (area ratio $=0.16$ ) of cement columns had been cured for 7, 14 and 28 days, after which they had been subjected to Rowe Cell consolidation testing. Results were also presented from tests conducted on groups of cement columns using four (area ratio $=0.04$ ) and nine (area ratio $=$ 0.09 ) columns of $15 \mathrm{~mm}$ in diameter each to investigate the influence of the number of cement columns on compressibility of peat. Based on the results obtained, compressibility indices $C_{c}$ and $C_{a}$ decreased with increasing diameter of the cement columns. It was also noticed that 28 days of curing time and larger diameter cement column have a significant effect on the final compressibility values. It had been suggested that increasing the number of cement columns reduce the compressibility of peat. It had been concluded that cement columns can successfully reduce the compressibility of fibrous peat.

Islam et al. [7] studied the engineering properties of stabilized peat soil using various types of binders by DMM. Some soil-cement model columns had been constructed at the site and different mechanical properties including undrained shear strength, UCS and shear strength had been determined after 14 days of curing period. Based on the test results, it had been found that the maximum UCS value of $16.4 \mathrm{kPa}$ and shear strength value of $1.60 \mathrm{MPa}$ had been obtained with $100 \%$ of Mascrete (Lafarge brand) cement, $\mathrm{CaCl}_{2}$ ( $4 \%$ of binder) and $25 \%$ of sand by volume of soil, as binder at a dosage of $300 \mathrm{~kg} / \mathrm{m}^{3}$. It had been concluded that the engineering properties of peat soil can be improved by stabilization using additives.

Kazemian et al. [8] investigated the effectiveness of using different ratios of cement-sodium silicate system grout compounds with kaolinite. Shear strength and micro-structural properties of stabilized sapric peat samples had been studied after 3 and 30 days of curing. It had been found that kaolinite is effective in increasing the shear strength and reducing the moisture content of the treated peat. Calcium chloride seemed to have different effects on the grout strength. It caused to increase shear strength of samples until the net charge of the sample changed to zero and then it decreased with further increase in calcium chloride. It had been also noticed that shear strength and density of the treated peat can be increased with a corresponding reduction in moisture content by increasing sodium silicate (within 3\%), cement and soaking time.

To date, there are no studies focusing on the DSM technique using fly ash as the binder to study the effect of single and multiple DSM columns to improve peat soil. Therefore, aim of this research was to study the compressibility behaviour of peat stabilized with low calcium fly ash using DSM technique. The detailed 
experimental methods and the results are explained in the following chapters.

\section{Materials and Methods}

\subsection{Materials}

Collections of samples were based on BS (1377) and the location of the sampling is shown in Figure 1. Undisturbed peat samples of $150 \mathrm{~mm}$ in diameter and $80 \mathrm{~mm}$ in height at a depth of $300 \mathrm{~mm}$ from the ground surface were collected from Muthurajawela area adjacent to Colombo Katunayake Expressway (CKE) (Figure 2). In order to maintain the in-situ moisture content, samples were waxed at the top and bottom surfaces. Class F fly ash was collected from Lakwijaya coal power plant, Norochcholai, Puttalam, Sri Lanka. Class F fly ash (low Ca fly ash) is produced by burning of harder, older anthracite and bituminous coal. According to ASTM C618, ash containing more than $70 \%$ by weight, addition of $\mathrm{SiO}_{2}, \mathrm{Al}_{2} \mathrm{O}_{3}$ and $\mathrm{Fe}_{2} \mathrm{O}_{3}$, and being low in lime are classified as Class F fly ash. Fly ash generated at Lakwijaya coal power plant is Class F fly ash and the composition of fly ash is shown in Table 1.
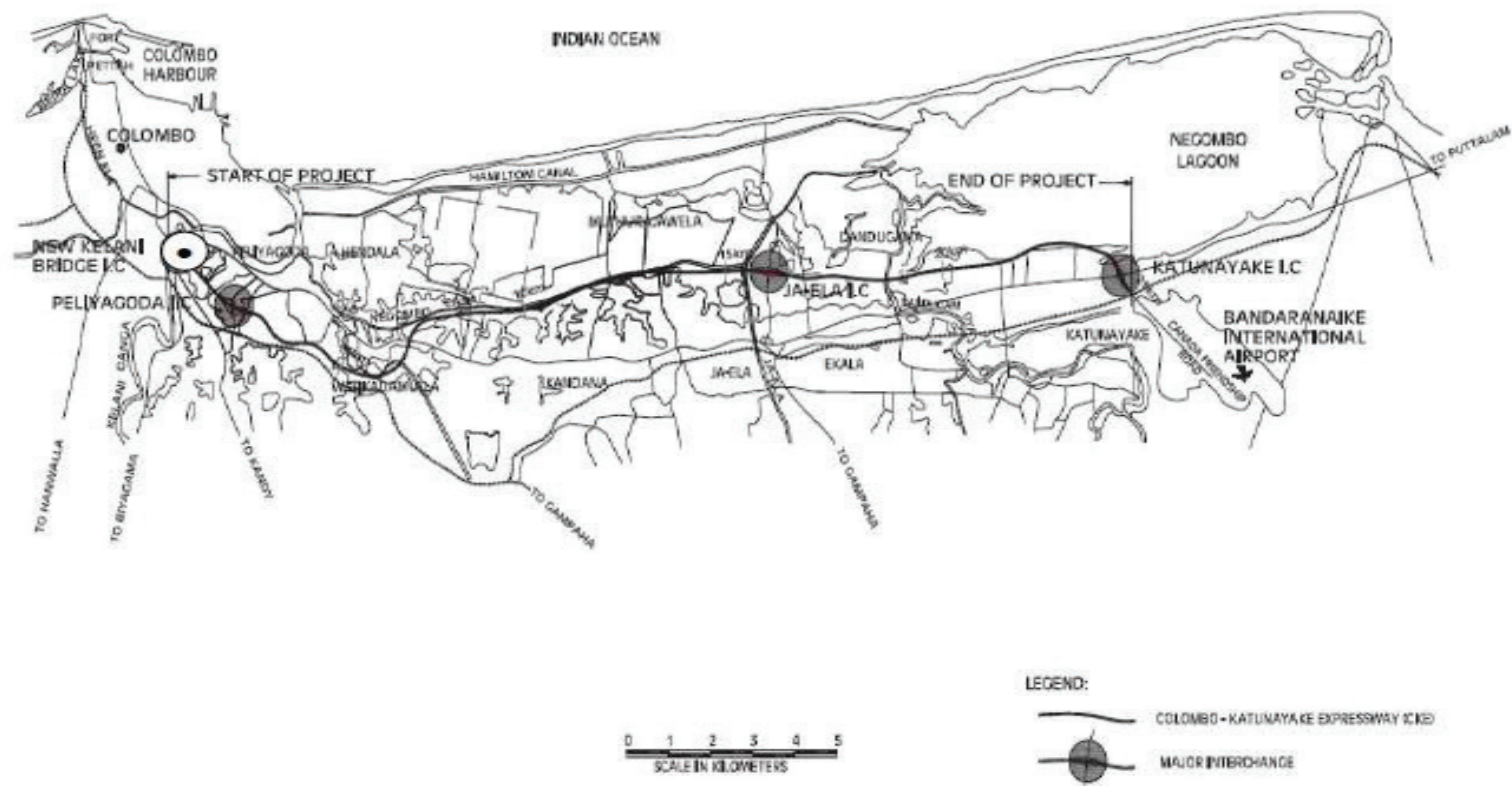

Figure 1 - Sampling Location Adjacent to CKE

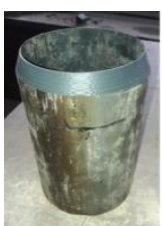

(a)

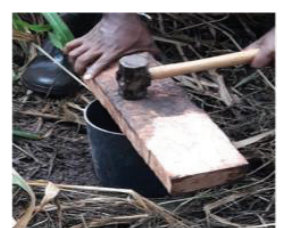

(b)

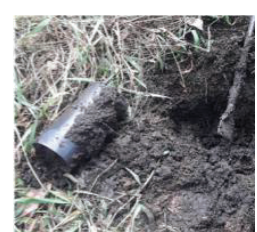

(c)
Figure 2 - Sampling: (a) PVC tube used for sampling; (b) Driving sample tube and (c) Extracted sample

Table 1 - Composition of Class F Fly Ash

\begin{tabular}{|c|c|}
\hline Constituents & Percentage (\%) \\
\hline $\mathrm{SiO}_{2}$ & 52.03 \\
\hline $\mathrm{Al}_{2} \mathrm{O}_{3}$ & 32.31 \\
\hline $\mathrm{Fe}_{2} \mathrm{O}_{3}$ & 7.04 \\
\hline $\mathrm{CaO}$ & 5.55 \\
\hline $\mathrm{MgO}$ & 1.30 \\
\hline $\mathrm{SO}_{3}$ & 0.07 \\
\hline $\mathrm{K}_{2} \mathrm{O}$ & 0.68 \\
\hline $\mathrm{Cl}$ & 1.00 \\
\hline
\end{tabular}

\subsection{Experimental Methodology}

\subsubsection{Index properties}

Index tests, including organic content (BS 1377 3-4: 1990), moisture content (BS 1377-2-3: 1990) specific gravity (BS 1377-2-8.4: 1990) and bulk unit weight (BS 1377-2-7: 1990), were conducted to determine the index properties of peat samples.

\subsubsection{Rowe cell test (BS 1377: part 6: 1990)}

Rowe cell tests were carried out to determine the compressibility parameters of raw peat and fly ash stabilized peat columns. Rowe cell has few advantages compared to the conventional oedometer test. The important features of Rowe cell are its ability to control drainage and to measure pore water pressure during the course of consolidation, and to overcome the disadvantage of the oedometer apparatus when performing consolidation tests on low 
permeability soil [11]. Sample size for the Rowe cell test was $150 \mathrm{~mm}$ in diameter and $50 \mathrm{~mm}$ in height. For the tests, three types of samples were used: (1) Raw peat (P) - $150 \mathrm{~mm}$ in diameter and $50 \mathrm{~mm}$ in height; (2) Peat with single DSM column (P-SC) - peat and fly ash mixed column of $60 \mathrm{~mm}$ in diameter placed at the centre and (3) Peat with multiple (DSM) columns (P-MC) Four numbers of peat fly ash mixed columns, with each $30 \mathrm{~mm}$ in diameter, were placed. Figure 3 shows the schematic view of three samples P, P- C and P-MC used for the Rowe cell test.
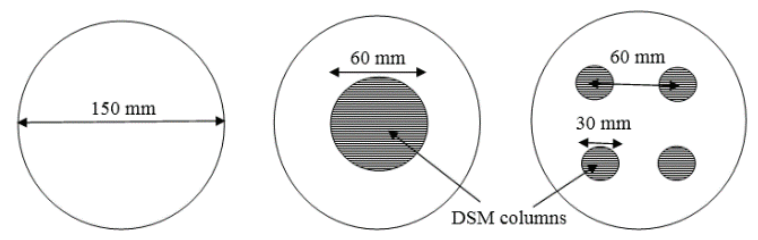

Figure 3 - Schematic View of the Samples (a) P, (b) P-SC and (c) P-MC

It should be noted that both P-SC and P-MC have a similar column area ratio value of $16 \%$. The DSM column was prepared as follows. A metal tube (diameter $30 \mathrm{~mm}$ or $60 \mathrm{~mm}$ ) was used to extract the peat sample from a $150 \mathrm{~mm}$ diameter raw peat sample to make the hollow column as shown in Figure 3. The extracted sample (diameter $30 \mathrm{~mm}$ or $60 \mathrm{~mm}$ ) was mixed with fly ash at a dosage of $50 \%$ by weight. The fly ash-peat mixture was thoroughly mixed for a period of five minutes to ensure a homogeneous mixture. The peat - fly ash mix was then placed in the hollow column formed in the raw peat (as shown in Figure 3) and it was compacted by applying 10 blows using a $2 \mathrm{~kg}$ hammer [6]. All the samples (P, P-SC and P-MC) were cured in a submerged water bath for a period of 28 days before commencing the Rowe cell consolidation test. A series of normal stresses of 20,40, 80, 160 and $320 \mathrm{kPa}$ were applied to the sample. Each load was kept for 3 days, and after applying all the normal loads, unloading was continued for a period of 24 hours. It is assumed that the loading time of three days is sufficient to complete the primary consolidation. In the test, an equal strain condition was maintained and one-way vertical drainage was allowed.

Initially, the drainage valve was closed and $10 \mathrm{kPa}$ back pressure was applied to the sample and allowed the pore pressure to reach $10 \mathrm{kPa}$ to ensure complete saturation. The back-pressure valve was then closed and a diaphragm pressure of $20 \mathrm{kPa}$ was applied. Both valves (back pressure and drainage) were then opened and allowed for saturation. Dial gauge was set to zero after the increase in pore pressure was equal to the applied diaphragm pressure. Drainage valve was opened and stop watch was activated simultaneously. The dial gauge reading was taken with corresponding time. These procedures were repeated for all the other normal stress values. Rowe cell apparatus used for the test is shown in Figure 4. Coefficient of primary consolidation $\left(\mathrm{c}_{\mathrm{v}}\right)$, coefficient of volume compressibility $\left(\mathrm{m}_{\mathrm{v}}\right)$ and permeability $(\mathrm{k})$ were calculated from the Rowe cell test results.

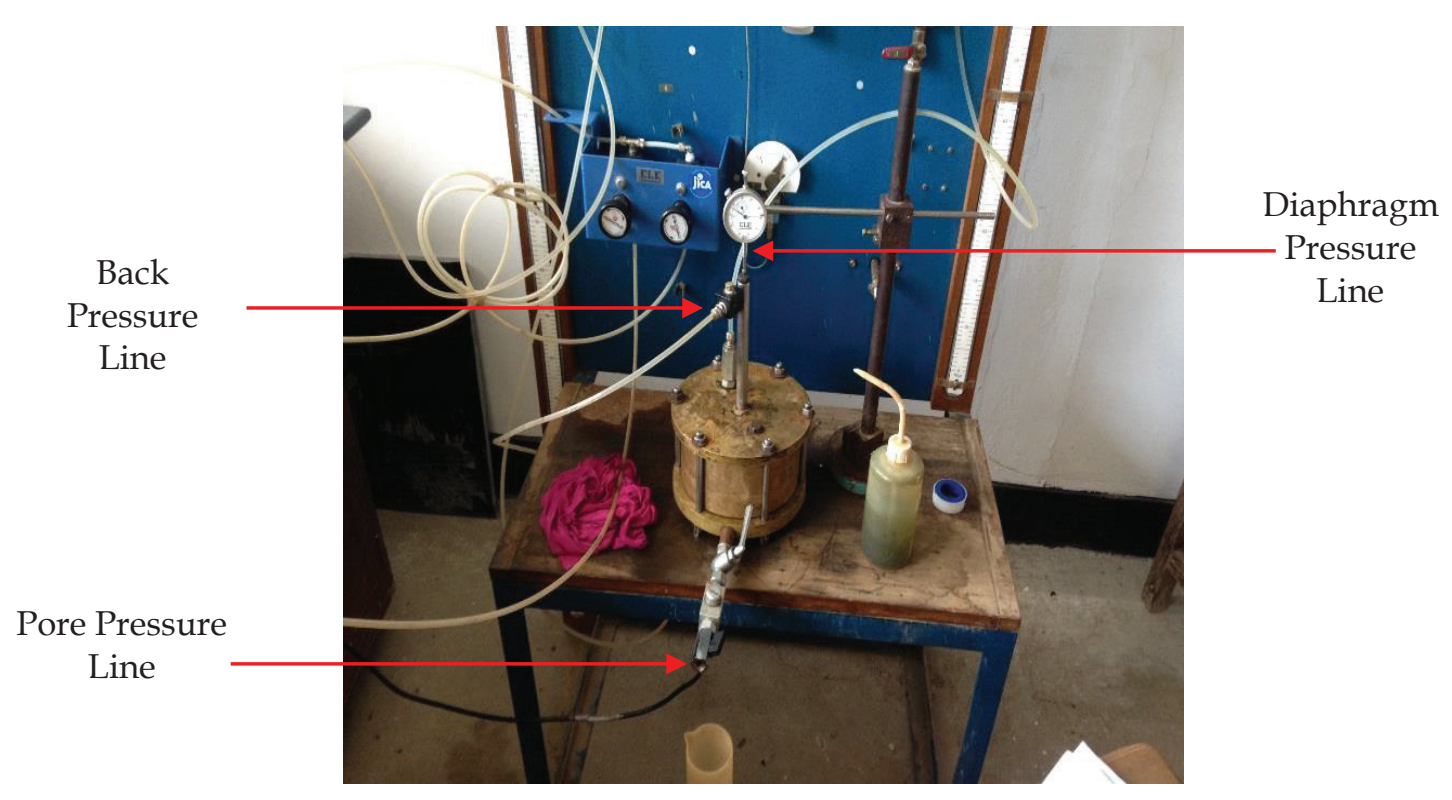

Figure 4 - Rowe cell Apparatus used for the Consolidation Test 
2.2.3 Direct shear test (BS 1377: part 7: 1990) Direct shear test was conducted for raw peat and peat stabilized with $50 \%$ fly ash content (fly ashpeat mixture used to prepare P-SC and P-MC samples) to obtain the shear strength parameters, cohesion (c') and effective friction angle $\left(\varphi^{\prime}\right)$ of the samples. A square sample of 60 $\mathrm{mm}$ length and $20 \mathrm{~mm}$ height was placed in the mould and $0.25 \mathrm{~mm} / \mathrm{min}$ shearing speed was applied to each sample under different normal loads of 50, 100, 200 and $300 \mathrm{kPa}$. Shear displacement, normal displacement and shear load readings were recorded.

\section{Results and Discussion}

\subsection{Index Properties of Peat}

Index properties of raw peat are tabulated in Table 2. Based on the index properties, this peat is classified as amorphous peat [15].

Table 2 - Values of Index Properties

\begin{tabular}{|l|c|}
\hline \multicolumn{1}{|c|}{ Parameters } & Values \\
\hline Bulk density, $(\rho)$ & $1151.9 \mathrm{~kg} / \mathrm{m}^{3}$ \\
\hline Moisture content, $(w)$ & $141.8 \%$ \\
\hline Dry density, $\left(\rho_{\mathrm{d}}\right)$ & $476.4 \mathrm{~kg} / \mathrm{m}^{3}$ \\
\hline Specific gravity $(\mathrm{GS})$ & 1.88 \\
\hline Liquid limit $(\mathrm{LL})$ & $100.0 \%$ \\
\hline Plastic limit $(\mathrm{PL})$ & $47.2 \%$ \\
\hline Organic content $(\mathrm{OC})$ & $76.7 \%$ \\
\hline
\end{tabular}

\subsection{Compressibility Characteristics of} Peat and Fly Ash Stabilized DSM Columns

Variation of settlement with square root time under different normal stresses for P, P-SC and $\mathrm{P}-\mathrm{MC}$ are shown in Figure 5. Coefficient of consolidation $\left(\mathrm{c}_{\mathrm{v}}\right)$ of the samples was obtained using Taylor's method. The $\mathrm{c}_{\mathrm{v}}$ value was found using Equation (1).

$$
\mathrm{c}_{\mathrm{v}}=\frac{0.848 \times \mathrm{H}_{\mathrm{d}}^{2}}{\mathrm{t}_{90}}
$$

where, $\mathrm{H}_{\mathrm{d}}$ is the drainage height of the sample and $t_{90}$, the time taken for $90 \%$ consolidation. Permeability (k) was calculated using Equation (2).

$$
\mathrm{k}=\mathrm{c}_{\mathrm{v}} \mathrm{m}_{\mathrm{v}} \gamma_{\mathrm{w}}
$$

where, $m_{v}$ is coefficient of volume compressibility and $\gamma_{\mathrm{w}}$ is unit weight of water.

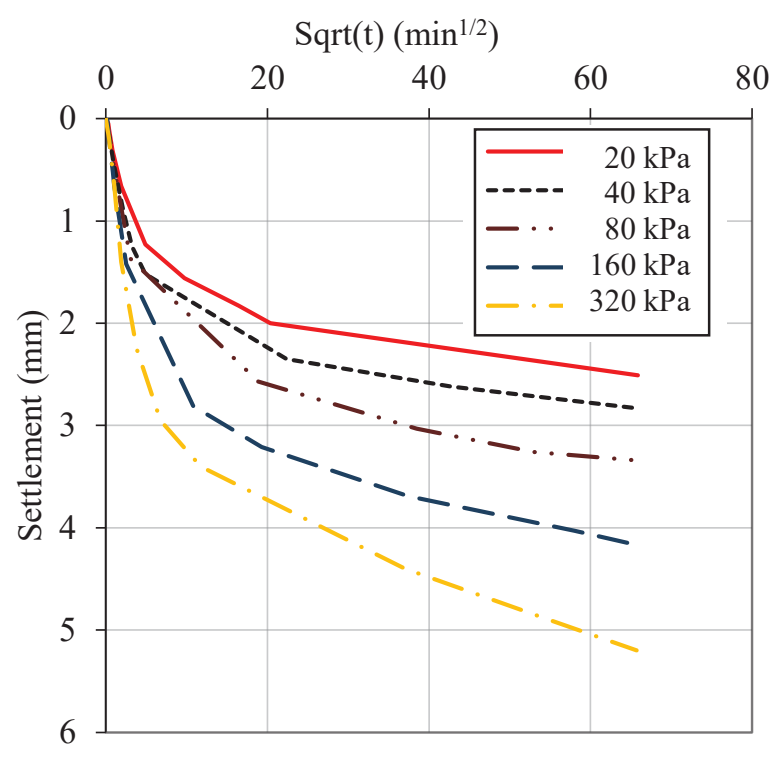

(a) $\mathrm{P}$

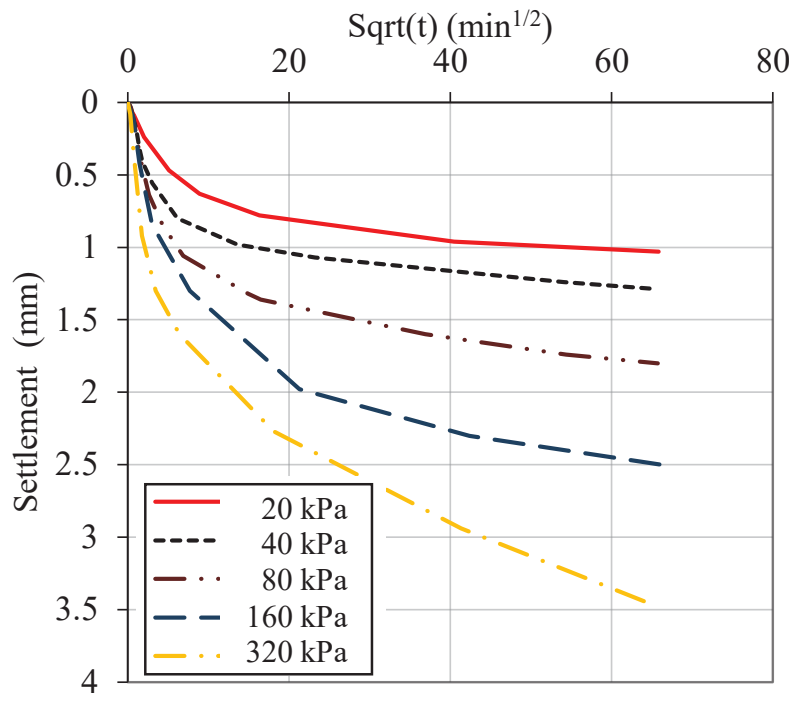

(b) P-SC

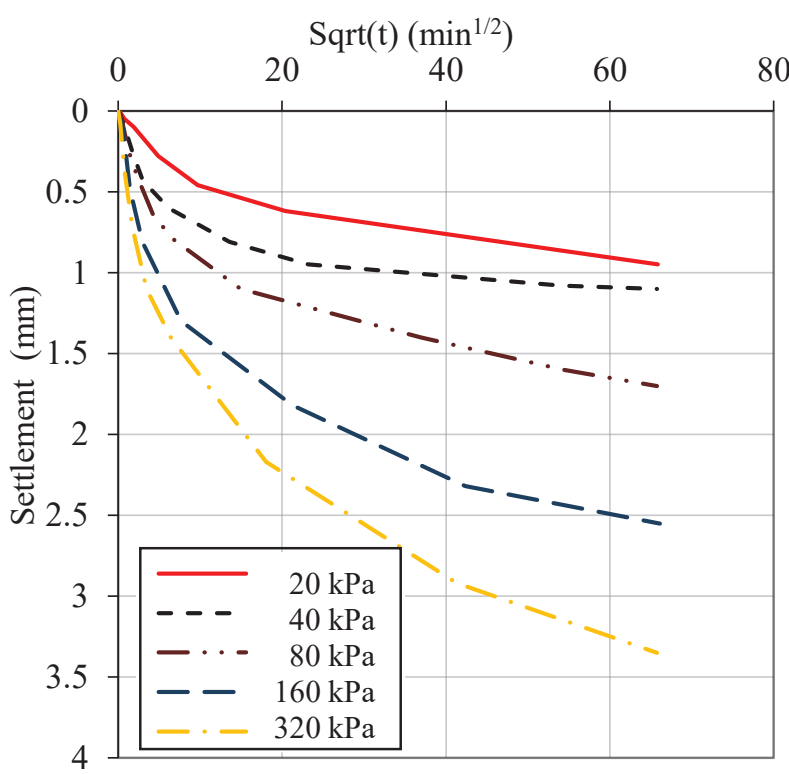

(c) P-MC

Figure 5 - Variation of Settlement with Sqrt (time) for (a) P, (b) P-SC and (c) P-MC 
Tables 3 to 5 show the consolidation parameters $\left(\mathrm{c}_{\mathrm{v}}, \mathrm{m}_{\mathrm{v}}\right.$ and $\mathrm{k}$ ) for P, P-SC and P-MC samples, respectively. Based on Tables 3 to 5 , it can be seen that $c_{V}$ values of all the samples increase with increase in normal stress. The coefficient of consolidation is an indicator of rate of drainage and higher $c_{V}$ values mean the rate of drainage of pore water is high. As expected, the rate of drainage increases with increase in normal stress as $C_{V}$ values increase with increase in normal stress values. It can also be seen that, for a given normal loading, $P$ samples possess the highest $c_{V}$ values, whereas P-MC samples have the lowest $\mathrm{C}_{\mathrm{V}}$ values (Tables 3 to 5 ).

Permeability values of the samples were determined using the $c_{v}$ and $m_{v}$ values calculated for each loading. The permeability values of P, P-SC and P-MC samples decrease with the increase in normal stress. Increase in normal stress reduces the voids in the soil, leading to reduced rate of drainage. Therefore, permeability values of $\mathrm{P}, \mathrm{P}-\mathrm{SC}$ and $\mathrm{P}-\mathrm{MC}$ reduce with increase in normal stress. For a given normal loading, the highest permeability values were obtained for sample $\mathrm{P}$, while the lowest values were obtained for P-MC samples (Tables 3 to 5). Due to the presence of peat-fly ash mixed columns in the P-MC sample, a pozzolanic reaction is induced between fly ash and water molecules in the peat. Pozzolanic reaction produces a stiff matrix in peat molecules and increases the packing of peat molecules $[6,10$, 15]. Due to the close packing of peat soil, rate of drainage reduces, leading to a reduction in permeability value. This is the reason for the observed reduced $\mathrm{C}_{\mathrm{V}}$ and $\mathrm{k}$ values for P-MC samples compared to $\mathrm{P}$ samples for a given normal loading.

Table 3 - Variation of Consolidation Parameters of $\mathbf{P}$

\begin{tabular}{|l|c|c|c|c|c|}
\hline \multirow{2}{*}{ Parameters } & \multicolumn{5}{|c|}{ Normal Stress (kPa) } \\
\cline { 2 - 6 } & 20 & 40 & 80 & $\mathbf{1 6 0}$ & 320 \\
\hline $\begin{array}{l}\mathrm{C}_{\mathrm{v}}(\mathrm{x} \mathrm{10}-7) \\
\left(\mathrm{m}^{2} / \mathrm{s}\right)\end{array}$ & 10.5 & 17.4 & 27.3 & 39.3 & 56.5 \\
\hline $\begin{array}{l}\mathrm{m}_{\mathrm{v}}\left(\mathrm{x} \mathrm{10} 0^{-4}\right) \\
\left(\mathrm{m}^{2} / \mathrm{kN}\right)\end{array}$ & 24.2 & 13.5 & 8.1 & 5.1 & 3.2 \\
\hline $\begin{array}{l}\mathrm{k}\left(\mathrm{x} 10^{-10}\right) \\
(\mathrm{m} / \mathrm{s})\end{array}$ & 25.4 & 23.5 & 22.2 & 20.0 & 18.0 \\
\hline
\end{tabular}

Table 4 - Variation of Consolidation Parameters of P-SC

\begin{tabular}{|l|c|c|c|c|c|}
\hline \multirow{2}{*}{ Parameters } & \multicolumn{5}{|c|}{ Normal Stress (kPa) } \\
\cline { 2 - 6 } & $\mathbf{2 0}$ & $\mathbf{4 0}$ & $\mathbf{8 0}$ & $\mathbf{1 6 0}$ & $\mathbf{3 2 0}$ \\
\hline $\begin{array}{l}\mathrm{C}_{\mathrm{V}}\left(\mathrm{x} 10^{-7}\right) \\
\left(\mathrm{m}^{2} / \mathrm{s}\right)\end{array}$ & 8.1 & 11.3 & 15.3 & 18.3 & 22.1 \\
\hline $\begin{array}{l}\mathrm{m}_{\mathrm{V}}\left(\mathrm{x} 10^{-4}\right) \\
\left(\mathrm{m}^{2} / \mathrm{kN}\right)\end{array}$ & 8.9 & 6.1 & 4.3 & 3.0 & 2.1 \\
\hline $\begin{array}{l}\mathrm{k}\left(\mathrm{x} 10^{-10}\right) \\
(\mathrm{m} / \mathrm{s})\end{array}$ & 7.2 & 6.9 & 6.6 & 5.5 & 4.7 \\
\hline
\end{tabular}

Table 5 - Variation of Consolidation Parameters of P-MC

\begin{tabular}{|l|c|c|c|c|c|}
\hline \multirow{2}{*}{ Parameters } & \multicolumn{5}{|c|}{ Normal Stress (kPa) } \\
\cline { 2 - 6 } & $\mathbf{2 0}$ & $\mathbf{4 0}$ & $\mathbf{8 0}$ & $\mathbf{1 6 0}$ & $\mathbf{3 2 0}$ \\
\hline $\begin{array}{l}\mathrm{C}_{\mathrm{V}}\left(\mathrm{x} 10^{-7}\right) \\
\left(\mathrm{m}^{2} / \mathrm{s}\right)\end{array}$ & 7.6 & 11.2 & 13.8 & 17.4 & 19.3 \\
\hline $\begin{array}{l}\mathrm{m}_{\mathrm{v}}(\mathrm{x} \mathrm{10-4}) \\
\left(\mathrm{m}^{2} / \mathrm{kN}\right)\end{array}$ & 8.3 & 5.0 & 4.0 & 3.0 & 2.0 \\
\hline $\begin{array}{l}\mathrm{k}\left(\mathrm{x} 10^{-10}\right) \\
(\mathrm{m} / \mathrm{s})\end{array}$ & 6.4 & 5.6 & 5.5 & 5.3 & 3.9 \\
\hline
\end{tabular}

Variation of void ratio with $\log$ stress $(\mathrm{e}-\log \sigma)$ for P, P-SC and P-MC are shown in Figure 6. The compression index $\left(\mathrm{C}_{\mathrm{c}}\right)$ and swell index $\left(\mathrm{C}_{\mathrm{s}}\right)$ values for different samples were calculated from e $-\log \sigma$ plots and the values are reported in Table 6. The $C_{s}$ value was determined from the slope of the rebound curve of $\mathrm{e}-\log \sigma$ (Figure 6).

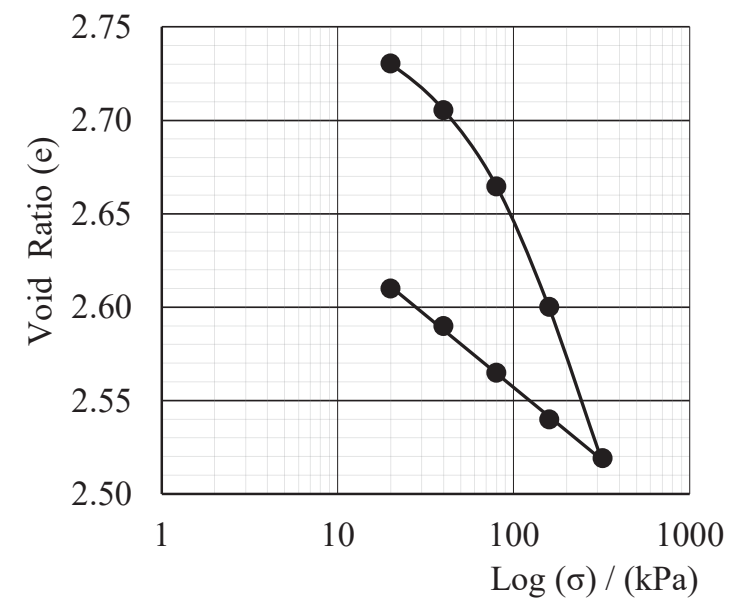

(a) $\mathrm{P}$ 


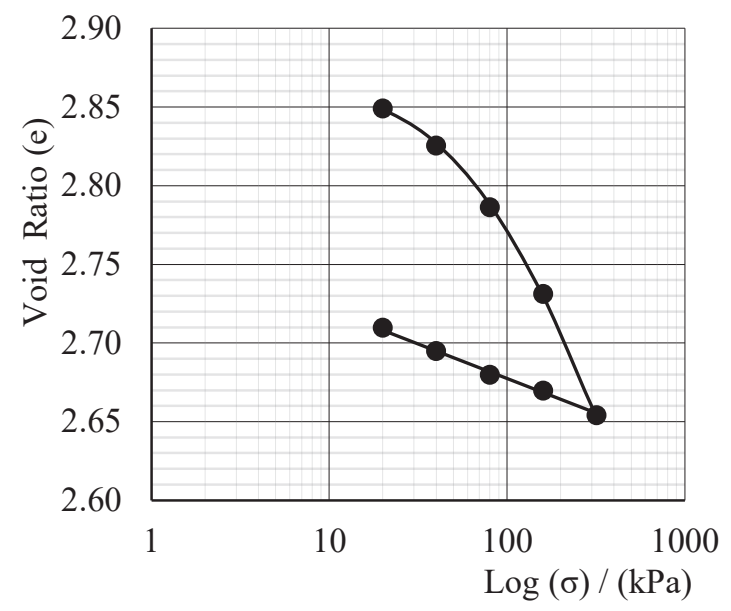

(b) P-SC

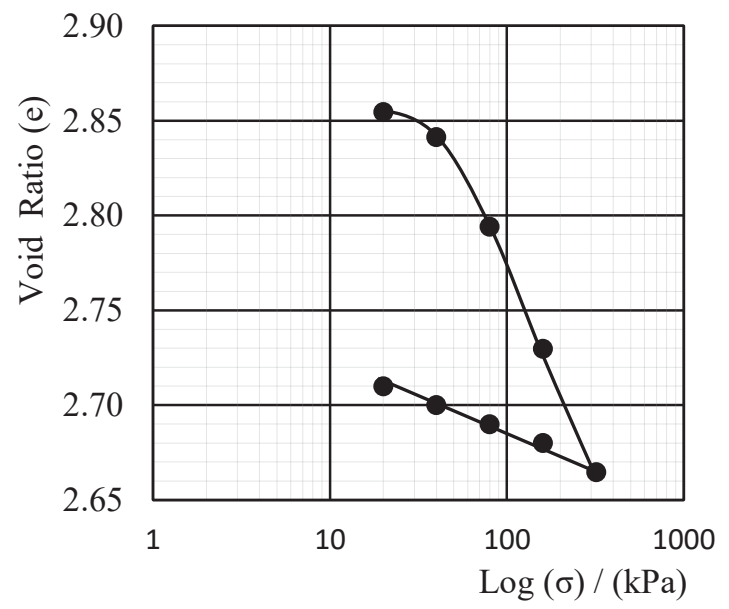

(c) P-MC

Figure 6 - Variation of Void Ratio with $\log$ of Effective Stress for (a) P, (b) P-SC and (c) P-MC Samples.

Table 6 - Compressibility Parameters

\begin{tabular}{|c|c|c|}
\hline Sample type & $\mathrm{C}_{\boldsymbol{c}}$ & $\mathrm{C}_{\mathbf{s}}$ \\
\hline $\mathrm{P}$ & 0.33 & 0.08 \\
\hline P-SC & 0.24 & 0.05 \\
\hline P-MC & 0.20 & 0.03 \\
\hline
\end{tabular}

It can be seen from Table 6 that $C_{c}$ value of raw peat reduces significantly when it is stabilized with fly ash. Addition of fly ash to peat promotes pozzolanic reaction as water from the peat is extracted for pozzolanic reaction producing a stiff matrix $[6,10,15]$. In addition, $\mathrm{P}-\mathrm{MC}$ sample showed the lowest values among all the three samples indicating higher effectiveness of $\mathrm{P}-\mathrm{MC}$ in reducing the compressibility compared to P-SC sample. Although P-SC and P-MC samples have the same area ratio, the total surface area of the DSM columns in contact with peat is high in the P-MC sample. This will lead to enhancing the pozzolanic reaction compared to the P-SC sample, thereby reducing the compressibility. Compression index of P-SC and $\mathrm{P}-\mathrm{MC}$ reduces by $27.3 \%$ and $39.4 \%$, respectively, while percentage reduction in swell index for P-SC and P-MC were $37.6 \%$ and $62.5 \%$, respectively compared to raw peat sample. For a given area ratio, provision of multiple columns are effective compared to a single column.

Previous researchers $(6,10,15)$ have also concluded that fly ash can be utilized as an effective binder to improve the geotechnical properties (compressive strength, bearing capacity and compressibility) of soft soils including peat. Further, Duraisamy et al. [3] have concluded that group of cement columns has a significant influence in reducing the compressibility parameters compared to a single column. Hence, it can be concluded that DSM technique can be used to reduce the compressibility of raw peat using fly ash as the admixture and multiple columns are more effective compared to a single DSM column.

\subsection{Shear Strength Properties of Peat and Fly Ash Stabilized Peat}

Direct shear tests were conducted for raw peat and peat stabilized with $50 \%$ fly ash content. Peak shear stress was considered in the calculation of effective cohesion (c') and effective friction angle $\left(\varphi^{\prime}\right)$ for both samples. Variation of shear stress against the shear displacement for raw peat and fly ash stabilized peat are shown in Figures 7 and 8, respectively.

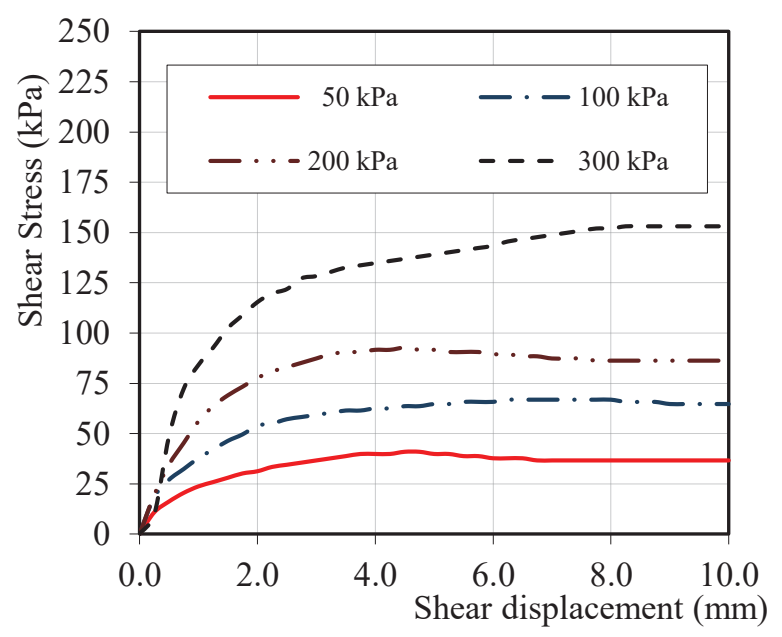

Figure 7 - Variation of Shear Stress against Shear Displacement for Raw Peat 


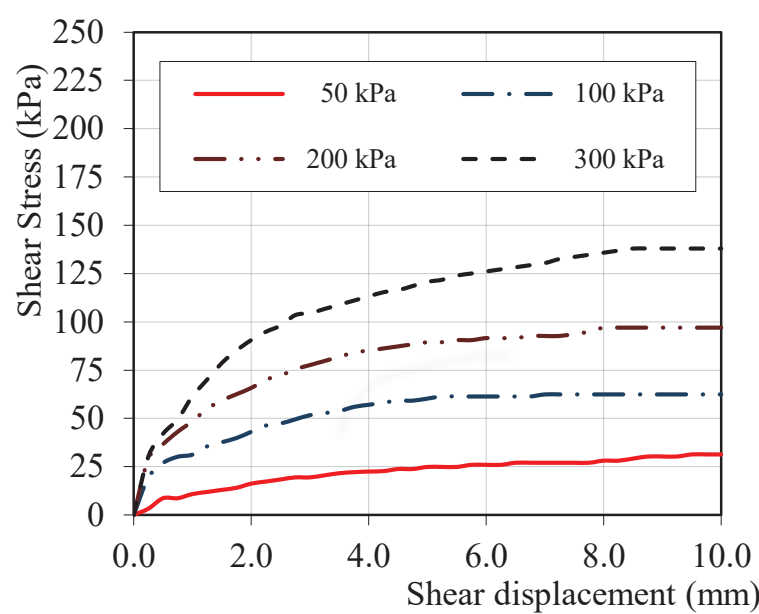

Figure 8 - Variation of Shear Stress against Shear Displacement for Fly Ash Stabilized Peat

Variations of shear stress against normal stress for raw peat and fly ash stabilized peat are shown in Figures 9 and 10, respectively.

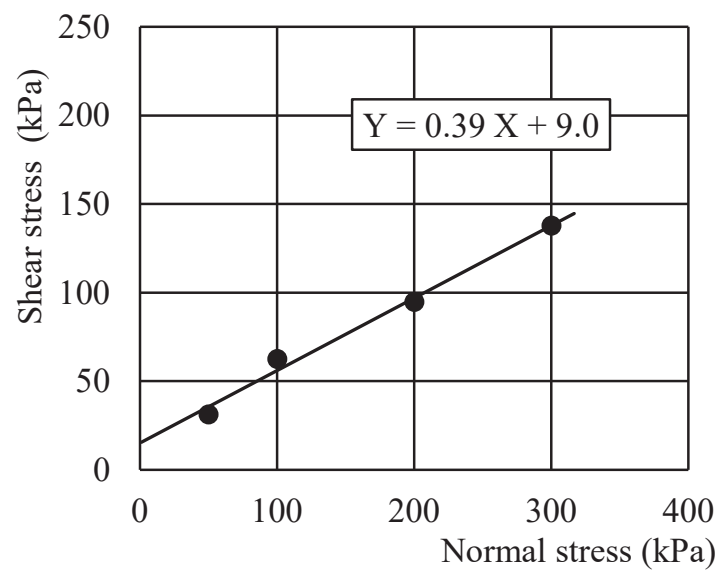

Figure 9 - Variation of Shear Stress with Normal Stress for Raw Peat

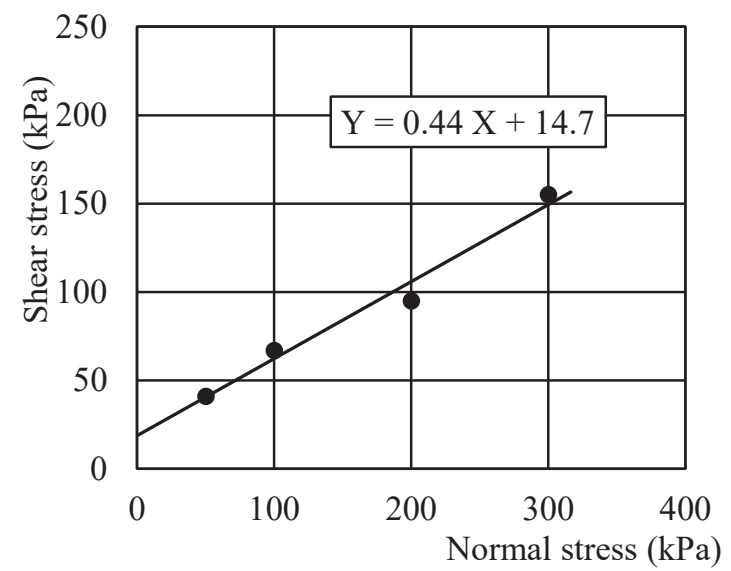

Figure 10 - Variation Shear Stress with Normal Stress for Fly Ash Stabilized Peat

Based on Figures 9 and 10, shear strength parameters of the samples were calculated and the results are given in Table 7. According to Table 7, effective shear strength parameters
( $c$ 'and $\varphi^{\prime}$ ) of fly ash stabilized peat are higher compared to that of raw peat. It is due to the pozzolanic reaction that produces a stiff matrix in peat molecules and increases the stiffness of stabilized peat $[6,15]$. Due to the addition of $50 \%$ fly ash, percentage increase in $c^{\prime}$ was $63.4 \%$, while the percentage increase in $\varphi^{\prime}$ was $11.7 \%$. It can be seen that the stabilized peat has higher effective shear strength parameters compared to raw peat, leading to enhance bearing capacity and reduce compressibility.

Table 7 - Shear Strength Parameters of Raw and Stabilized Peat

\begin{tabular}{|c|c|c|}
\hline Sample & $\begin{array}{c}\text { Effective } \\
\text { cohesion } \\
\left(\boldsymbol{c}^{\prime}\right) \mathbf{( k P a )}\end{array}$ & $\begin{array}{c}\text { Effective } \\
\text { friction angle } \\
\left(\boldsymbol{\varphi}^{\prime}\right) \mathbf{( o )}\end{array}$ \\
\hline Raw peat & 9.0 & 21.3 \\
\hline $\begin{array}{c}\text { Fly ash } \\
\text { stabilized } \\
\text { peat }\end{array}$ & 14.7 & 23.8 \\
\hline
\end{tabular}

\section{Conclusions}

This study was carried out to investigate the compressibility behaviour of peat stabilized with fly ash using deep soil mixing method (DSM). A series of Rowe cell consolidation tests were conducted for three different types of samples: (1) Raw peat (P); (2) Peat with single DSM column (P-SC); and (3) Peat with multiple DSM columns (P-MC). The area ratio used for both P-SC and P-MC was same at $16 \%$, and 50\% fly ash (by weight) was used to stabilize the peat soil. In addition, direct shear tests were also conducted to study the effectiveness of fly ash on the improvement of shear strength parameters of fly ash stabilized peat.

Based on the findings of this study, it was noticed that the P-MC samples possess the lowest coefficient of consolidation $\left(c_{V}\right)$ and permeability $(\mathrm{k})$ values among all the samples and it is because of the reduced drainage rate in the P-MC sample due to the pozzolanic reaction between fly ash and water in the peat sample. Compressibility parameters such as compression index $\left(C_{c}\right)$ and swell index $\left(C_{s}\right)$ reduce significantly with the addition of fly ash. Compared to raw peat, percentage reductions in $\mathrm{C}_{\mathrm{c}}$ and $\mathrm{C}_{\mathrm{s}}$ for P-SC sample were $27.3 \%$ and $37.6 \%$, and for the P-MC sample, $39.4 \%$ and $62.5 \%$, respectively. It was concluded that, for a given area ratio, multiple DSM columns are more 
effective than a DSM single column in reducing the compressibility parameters.

In addition, it was also noticed that effective shear strength parameters $\left(c^{\prime}\right.$ and $\left.\varphi^{\prime}\right)$ of raw peat increased with the addition of fly ash, thereby leading to enhanced bearing capacity and reduced settlement. All in all, DSM technique can successfully be used to improve the compressibility characteristics of peat land.

\section{References}

1. Dehghanbanadaki, A., Ahmad, K. and Ali, N. (2014), "Experimental Investigations on Ultimate Bearing Capacity of Peat Stabilized by a Group of Soil-Cement Column: A Comparative Study", ActaGeotechnica.

2. Duraisamy, Y., Huat, B. B. K. and Aziz, A. A. (2007), "Engineering Properties and Compressibility Behaviour of Tropical Peat Soil", American Journal of Engineering and Applied Sciences, 4, Vol 10, pp. 768-773.

3. Duraisamy, Y., Haut, B. B. K. and Muniyandy, R. (2009), "Compressibility Behaviour of Fibrous Peat Reinforced with Cement Columns", GeotechGeolEng Vol. 27: pp. 619-629.

4. Huat, B. B. K., Maali, S. and Mohamed, T. A. (2005), "Effect of Chemical Admixtures on the Engineering Properties of Tropical Peat Soils", American Journal of Engineering and Applied Sciences 2, Vol 7, pp. 1113-112.

5. Huat, B. B. K. (2006), "Deformation and Shear Strength Characteristics of Some Tropical Peat and Organic Soils", Pertanika Journal Science and Technology, Volume 14(1 \& 2), pp. 61-67.

6. Huat, B. B. K., Kazemian, S., Prasad A. and Barghchi, M. (2011), "A Study of the Compressibility Behaviour of Peat Stabilized by DMM: Lab Model and FE Analysis", Scientific Research and Essays, Vol. 6(1), pp. 196-204.

7. Islam, M. S. and Hashim, R. (2008), "Properties of Stabilized Peat by Soil-Cement Column Method", Electronic Journal of Geotechnical Engineering, Vol 13, 1-9.

8. Kazemian, S., Prasad, A., Huat, B. B. K., Bazaz, J. B., Farah, N. A., Abdul, A., Thamer, A. and Mohammad Ali (2011), "Influence of Cement Sodium Silicate Grout Admixed with Calcium Chloride and Kaolinite on Sapricpeat", Journal of Civil Engineering and Management, Vol. 17:3, pp. 309-318.
9. Kazemian, S., Prasad, A., Huat, B. B., Mohammad, T. A. and Aziz, F. N. A. (2013), "Stabilization of Tropical Peat by Chemical Grout", Journal of the Chinese Institute of Engineers, 36(1),

pp.114-128.

10. Kolay, P. K., Sii, H. Y., and Taib, S. N. L. (2011), "Tropical Peat Soil Stabilization Using Class F Pond ash From Coal Fired Power Plant", International Journal of Civil and Environmental Engineering 3., Vol 2, 2011, pp. 79-83.

11. Lee, K. I., White, W. and Ingles, G. O. (1983), Geotechnical Engineering: Soil Mechanics. Boston: Pitman Publication. 405-406.

12. Murthy, V. N. S. (2003), Geotechnical Engineering, Principle and Practices of Soil Mechanics and Foundation Engineering, New York: Marcel Dekker. 227 \& 981-982.

13. Raghunandan, M. E. and Sriraam, A. S. (2017), "An Overview of the Basic Engineering Properties of Malaysian Peats", GeodermaRegional, 11, pp.1-7.

14. Sing, W. L., Hashim, R. and Ali, F. H. (2008), "Behaviour of Stabilized Peat Soils in Unconfined Compression Tests", American Journal of Engineering and Applied Sciences 1, Vol. 4, pp. 274279.

15. Venuja, S., Mathiluxsan, S. and Nasvi, M. C. M. (2017), "Geotechnical Engineering Properties of Peat, Stabilized with a Combination of Fly Ash and Well Graded Sand", Engineer: Journal of the Institution of Engineers, Sri Lanka, 50(2).

16. Woods, B. K., Berry, S. D. and Goetz, H. W. (1960), Highway Engineering Handbook, Sec. 21-7 New York: McGraw-Hill 21-123. 